\title{
Роль індексу перитонеального карциноматозу в стратегії лікування серозного раку яєчників IIIc-IV стадій
}

\author{
Національний інститут раку, Київ \\ Одержано: 20.09.2021 \\ Прийнято до друку: 25.09.2021 \\ DOI: 10.32471/clinicaloncology.2663-466X.41-1.27869
}

\begin{abstract}
Рак яєчників (РЯ) - одне з найбільш агресивних та складних захворювань жіночої статевої сфери. В Україні щорічно реєструють понад 3500 нових випадків захворювання, 22,7\% хворих помирають протягом першого року після встановлення діагнозу. Це вказує на актуальність розробки нових та оптимізації існуючих програм лікування РЯ. Мета. Проаналізувати результати лікування хворих з первинним розповсюдженим серозним РЯ з високим індексом перитонеального карциноматозу (index of peritoneal carcinomatosis - PCI $\geq 12$ ) за такими показниками: ступінь агресивності хірургічного втручання, післяопераційні ускладнення, тривалість перебування у відділенні реанімації та стаціонарі, терміни початку хіміотерапії, у порівнянні з групою хворих з нижчим $\mathrm{PCl}(<12)$ після циторедуктивних операцій. Матеріали та методи. Було проаналізовано результати лікування 50 хворих із розповсюдженим серозним РЯ, що проходили лікування у відділенні онкогінекології Національного інституту раку з 2016 до 2020 р. Для оцінки обсягу хірургічних процедур було використано систему оцінки складності хірургічного втручання, що забезпечує кількісну оцінку кожної хірургічної процедури. 50 хворих було поділено на дві групи порівну залежно від значення РCI: $\geq 12-25$ хворих - досліджувана група і РСl $<12-25$ хворих - контрольна група. Результати. Наприкінці 1-го дня післяопераційного періоду (POD-0) були виявлені статистично значущі зміни (p<0,05) у рівнях аланінамінотрансферази та аспартатамінотрансферази у хворих із $\mathrm{PCl} \geq 12$, що свідчить про розвиток порушення функції печінки в цій групі. Плеврит та анемія тяжкого ступеня є найчастішими ускладненнями післяопераційного періоду, що значно частіше $(p<0,05)$ виявляють у хворих з високим $\mathrm{PCl}$ порівняно з контрольною групою. Виявлена статистично вірогідна різниця $(p<0,05)$ у тривалості перебування хворих у відділенні реанімації та стаціонарі між досліджуваною та контрольною групами. Так, хворі з $\mathrm{PCl} \geq 12$ перебували у відділенні реанімації та стаціонарі після циторедуктивних операцій достовірно довше. Висновки. Отримані дані вказують на те, що проведення циторедуктивних операцій у хворих з високим $\mathrm{PCl} є$ надзвичайно агресивною процедурою, що істотно порушує функціонування ряду органів і систем організму, збільшує кількість ускладнень хірургічного та нехірургічного профілю у післяопераційний період, подовжує терміни стаціонарного лікування таких хворих. Високий $\mathrm{PCl}(\geq 12)$ у поєднанні з сумнівною перспективою виконання повної циторедукції (можливість досягнення рівня R0 щодо резидуальної пухлини), наявність тяжкої супутньої патології є критеріями вибору неоад'ювантної поліхіміотерапії у стратегії лікування раку яєчників IIIc-IV стадій.
\end{abstract}

Ключові слова: серозний рак яєчників; хірургічне лікування; циторедукція; індекс перитонеального карциноматозу.

Рак яєчників (РЯ) - одне з найбільш агресивних та складних захворювань жіночої статевої сфери. Щороку в Україні виявляють понад 3500 нових випадків цієї онкопатології. За оновленими даними Національного канцерреєстру, у 2019 р. було зареєстровано 3545 нових випадків РЯ [1]. Рівень захворюваності на цю патологію в Україні був стабільним протягом останніх 3 років, і в 2019 р. становив, за уточненими даними Національного канцер-реєстру, 18,6 на 100000 жіночого населення. Подібна тенденція спостерігається і в показниках смертності. У 2019 р. смертність від РЯ в Україні становила 9,0 на 100000 жіночого населення. Протягом першого року після встановлення діагнозу помирає близько 22,7\% пацієнток [1].

Усе вищесказане свідчить про актуальність розробки нових та оптимізації наявних програм лікування РЯ.

Метою дослідження є аналіз результатів лікування хворих з первинним розповсюдженим серозним РЯ з високим індексом перитонеального карциноматозу (index of peritoneal carcinomatosis - PCI $\geqslant 12$ ) за такими показниками, як ступінь агресивності хірургічного втручання, післяопераційні ускладнення, тривалість перебування у відділенні реанімації та стаціонарі, терміни початку ад’ювантної хіміотерапії у порівнянні з групою хворих з нижчим РСI $(<12)$ після циторедуктивних операцій (ЦРО).

\section{МАТЕРІАЛИ ТА МЕТОДИ}

Було проведено аналіз результатів лікування 50 хворих із розповсюдженим серозним РЯ, які лікувалися у від- діленні онкогінекології Національного інституту раку у період 2016-2020 pp. Усі пацієнтки були детально поінформовані про дослідження, і воно було схвалено місцевим комітетом з етики.

Клінічні характеристики хворих з розповсюдженим серозним РЯ IIIc-IV стадій наведені в табл. 1.

25 (50\%) хворих з розповсюдженим серозним РЯ мали високий PCI $(\geqslant 12)$ - досліджувана група. Та у 25 (50\%) пацієнтів відмічали нижчий PCI $(<12)-$ контрольна група.

Обсяг циторедукції був задокументований відповідно до вимог протоколу Свропейського товариства гінекологічних онкологів (European Society of Gynaecological Oncology ESGO; ESGO Guidelines, Recommendations and Assurance Quality Committee, 2016) [2].

Таблиця 1. Загальна клінічна характеристика пацієнток з РЯ

\begin{tabular}{|c|c|c|}
\hline \multirow{2}{*}{ Показники } & \multicolumn{2}{|c|}{ Кількість хворих } \\
\hline & $\mathbf{N}$ & $\%$ \\
\hline Усього & 50 & 100 \\
\hline \multicolumn{3}{|l|}{ Вік хворих (роки) } \\
\hline Середній & \multicolumn{2}{|c|}{$\begin{array}{c}50,4 \pm 1,7 \\
\text { (23-70 років) }\end{array}$} \\
\hline \multicolumn{3}{|l|}{ Стадія } \\
\hline III & 41 & 82 \\
\hline IV & 9 & 18 \\
\hline \multicolumn{3}{|l|}{ Ступінь диференціювання пухлини (G) } \\
\hline Помірна (G2) & 10 & 20 \\
\hline Низька (G3) & 26 & 52 \\
\hline Псамомний рак (Gx) & 9 & 18 \\
\hline Ступінь диференціювання (G) не вказано & 5 & 10 \\
\hline
\end{tabular}


Для оцінки обсягу проведених хірургічних втручань та прогнозування можливих післяопераційних ускладнень було використано систему оцінки складності хірургічного втручання (Surgical Complexity Scoring System - SCS), що забезпечувала кількісну оцінку кожної хірургічної процедури [3]. Кожна пацієнтка отримувала бали відповідно до обсягу виконаної операції.

Підтримувальна терапія після хірургічного лікування базувалася на протоколах мультимодального знеболення, антибактеріальної терапії, ERAS 2016, MASCC та ESMO, а також протоколі анестезії та інтенсивної терапії, розробленому в Національному інституті раку.

Ад'ювантна поліхіміотерапія (АПХТ), згідно з протоколом ТС (паклітаксел + карбоплатин) як стандарт лікування РЯ першої лінії [4], включала внутрішньовенне введення карбоплатину (AUC6) та паклітакселу (175 мг/м²) кожні 3 тиж.

Для обробки даних використовувалися стандартні методи описової статистики, зокрема, середні значення були розраховані з їх стандартними помилками. Різницю між досліджуваними групами оцінювали за допомогою $t$-критерію Стьюдента для кількісних показників та U-критерію Манна - Уїтні для номінальних (якісних) показників. Критичний рівень статистичної значущості був прийнятий рівним 0,05 .

\section{РЕЗУЛЬТАТИ}

Повну циторедукцію (R0) було проведено у 19 (76\%) хворих досліджуваної групи та 20 (80\%) пацієнтів контрольної групи (табл. 2) (p>0,05). Тож хворі досліджуваної та контрольної груп не відрізнялися за обсягом ЦРО, тобто групи були статистично однорідними.

ЦРО середньої складності включали гістеректомію з двосторонньою аднексектомією, оментектомію, тазову перитонектомію, стрипінг діафрагми, апендектомію, холецистектомію (4-7 балів) (рис. 1).

Операції високої складності включали гістеректомію з двосторонньою аднексектомією, оментектомію, стрипінг діафрагми з резекцією центрального сухожилля діафрагми, низьку передню резекцію прямої кишки, видалення вогниш пухлини на брижі клубової кишки та висхідної ободової кишки, резекцію клубової кишки та апендектомію (8-13 балів) (рис. 2-3).

Ми проаналізували результати лікування після ЦРО у хворих з первинним (нерецидивуючим) розповсюдженим серозним РЯ у досліджуваній та контрольній групах за такими показниками: ступінь агресивності хірургічного втручання, післяопераційні ускладнення, тривалість перебування хворих у відділенні реанімації та стаціонарі, терміни початку АПХТ.

Було досліджено ступінь агресивності циторедуктивного хірургічного лікування за результатами зміни таких фізіологічних показників, як креатинін, загальний білок, аланінамінотрансфераза (АлАТ), аспартатамінотрансфераза (АсАТ) у сироватці крові в кінці першого дня післяопераційного періоду (POD-0) у хворих досліджуваної та контрольної груп. Заслуговує на увагу наявність статистично значущої різниці в рівнях АлАТ $(\mathrm{p}=0,02, \mathrm{p}<0,05)$ та АсAТ $(\mathrm{p}=0,005, \mathrm{p}<0,05)$, що свідчить про достовірність наявності погіршення функції печінки у хворих із групи РCI $\geqslant 12$ наприкінці першої доби післяопераційного періоду (табл. 3).

Ми визначили найбільш поширені хірургічні та нехірургічні ускладнення в обох групах хворих. Серед найчастіших хірургічних ускладнень (табл. 4) слід відмітити плеврит, який

Таблиця 2. Розподіл хворих з РЯ залежно від об'єму ЦРО

\begin{tabular}{lcc}
\hline \multirow{2}{*}{ Об'єм цРО } & \multicolumn{2}{|c}{ Кількість спостережень, $\mathbf{n ~ ( \% ) ~}$} \\
\cline { 2 - 3 } & $\begin{array}{c}\text { Досліджувана } \\
\text { група (PCI } \geqslant 12)\end{array}$ & $\begin{array}{c}\text { Контрольна } \\
\text { група (PCI <12) }\end{array}$ \\
\hline Повна циторедукція (R0) & $19(76 \%)$ & $20(80 \%)$ \\
Оптимальна циторедукція (R1) & $6(24 \%)$ & $5(20 \%)$ \\
Усього & $25(100 \%)^{*}$ & $25(100 \%)$ \\
\hline
\end{tabular}

${ }^{*} \mathrm{p}>0.05, \mathrm{n}=50 ; \mathrm{U}-$ критерій Манна - Уїтні $(\mathrm{p}=0.81)$ було діагностовано на 2-5-й день у пацієнток обох груп. У групі з РСI $\geqslant 12$ плеврит відмічали значно частіше $(\mathrm{p}<0,05)$. Інші хірургічні ускладнення ступеня тяжкості IIIb згідно з Clavien Dindo, що вимагали повторної лапаротомії, пов'язаної з неспроможністю кукси, некрозом стоми, кровотечею після ЦРО були діагностовані в 5 (20\%) випадках у досліджуваній групі та в 1 (4\%) випадку в контрольній групі.

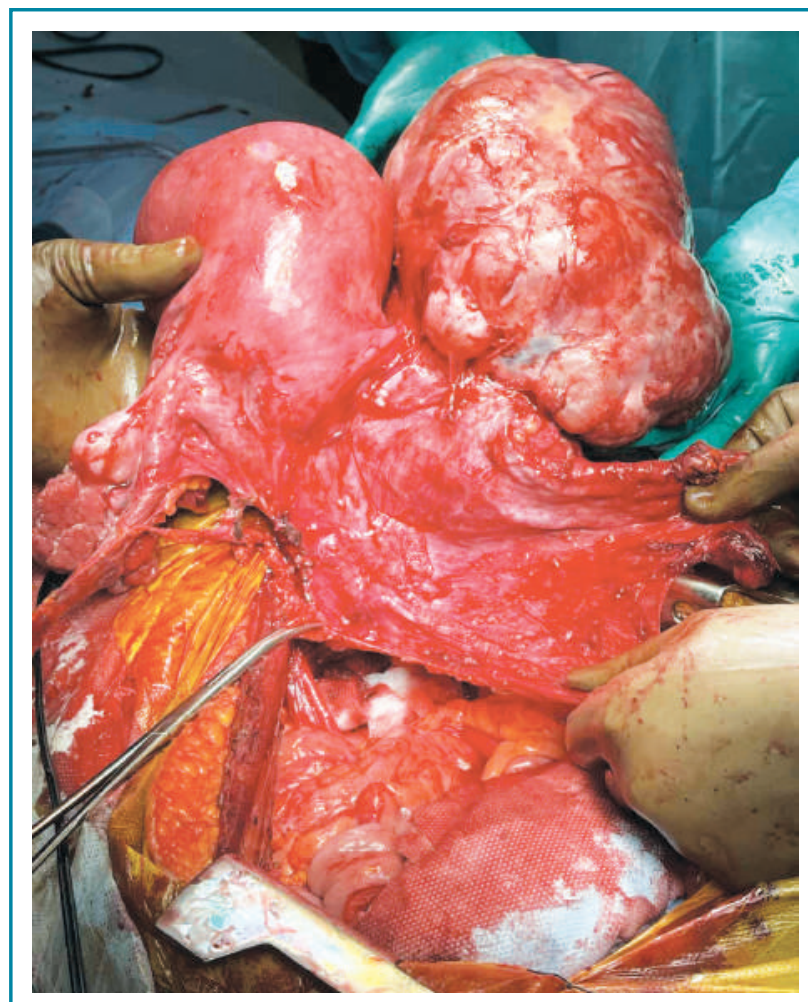

Рис. 1. ЦРО середньої складності (7 балів) у хворої А., $\mathrm{PCl}<12$

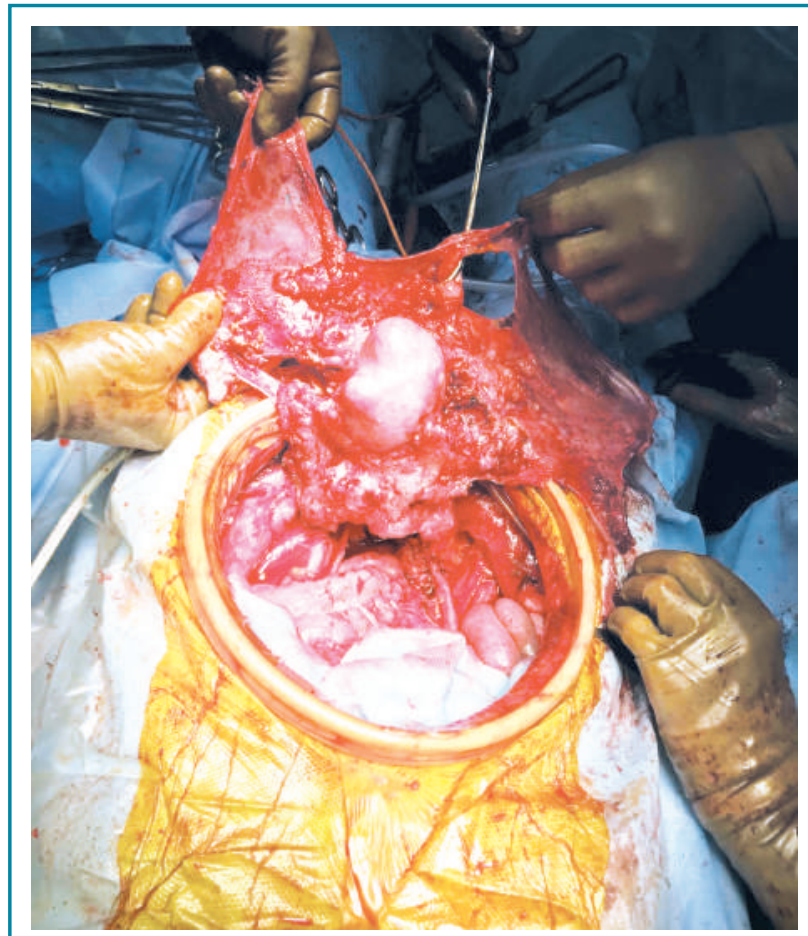

Рис. 2. ЦРО високої складності (13 балів) у хворої Б., РСІ $\geqslant 12$ 


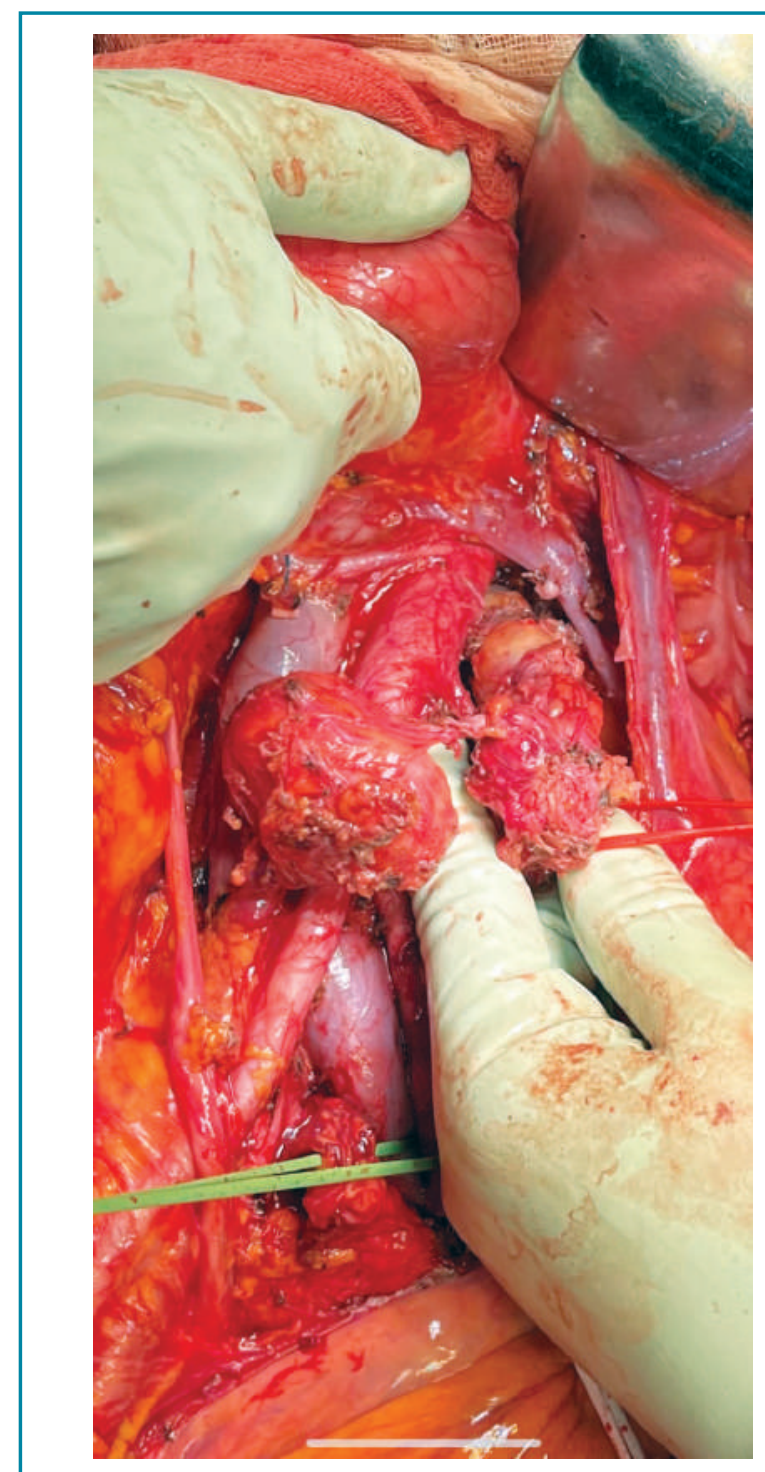

Рис. 3. ЦРО високої складності (13 балів) у хворої Б., РСІ $\geqslant 12$

Серед найбільш частих нехірургічних ускладнень у післяопераційний період ми виявили анемію легкого та середнього ступеня тяжкості, яка спостерігалася у 7 (28\%) хворих досліджуваної групи та у 15 (60\%) пацієнтів контрольної групи $(\mathrm{p}=0,02)$, різниця статистично вірогідна. Тяжка анемія (що потребувала гемотрансфузії) була діагностована у 14 (56\%) хворих досліджуваної групи та у 4 (16\%) пацієнтів контрольної групи $(\mathrm{p}=0,015)$, різниця статистично вірогідна.

Ми проаналізували безпосередні результати лікування хворих обох груп за такими показниками, як тривалість перебування у відділенні реанімації, стаціонарного лікування після операції, а також терміни початку лікування із застосуванням ад’ювантної хіміотерапії (табл. 5).

Згідно з результатами нашого аналізу, хворі з високим РСI перебували у відділенні реанімації достовірно довше $(\mathrm{p}=0,033)$ в порівнянні з контрольною групою.

Те саме можна сказати про більш тривалий термін стаціонарного лікування хворих з групи РСI $\geqslant 12$ після операції в порівнянні із цим показником у хворих з нижчим PCI $(\mathrm{p}=0,004)$.

Не виявлено статистично значущої різниці у термінах початку АПХТ між групами хворих.

Тож, достовірно довший термін післяопераційного лікування у відділенні реанімації та стаціонарі у хворих з високим PCI може бути пов'язаний з більшою хірургічною
Таблиця 3. Зміни фізіологічних показників у хворих досліджуваної групи $(\mathrm{PCl} \geqslant 12)$ та контрольної групи $(\mathrm{PCl}<12)$ в кінці 1-ї доби післяопераційного періоду (POD-0)

\begin{tabular}{lcc}
\hline \multicolumn{1}{c}{ Фізіологічний по- } & $\mathbf{P C I} \geqslant \mathbf{1 2}(\mathbf{n = 2 5 )}$ & $\mathbf{P C I}>\mathbf{1 2}(\mathbf{n = 2 5})$ \\
\multicolumn{1}{c}{ казник } & $\mathbf{P O D}-\mathbf{0}$ & $\mathbf{P O D}-\mathbf{0}$ \\
\hline Креатинін (мкмоль/л) & $101 \pm 6,3$ & $84,8 \pm 10,4$ \\
Загальний білок (г/л) & $53,6 \pm 4,1$ & $56,0 \pm 2,3$ \\
АлАТ (МО/л) & $74,95 \pm 13,24^{\star}$ & $37,72 \pm 7,31$ \\
АСТ(MO/л) & $78,19 \pm 13,41^{*}$ & $34,9 \pm 6,16$ \\
\hline
\end{tabular}

${ }^{*} \mathrm{p}<0.05$ - різниця між досліджуваною і контрольною групою статистично значуща

Таблиця 4. Хірургічні та нехірургічні ускладнення в післяопераційний період у групах хворих

\begin{tabular}{|c|c|c|c|}
\hline Ускладнення & $\begin{array}{c}\text { Ступінь тяжкості } \\
\text { за Clavien - Dindo }\end{array}$ & $\begin{array}{c}\mathrm{PCI} \geqslant 12 \\
(\mathrm{n}=25)\end{array}$ & $\begin{array}{l}\mathrm{PCl}<12 \\
(\mathrm{n}=25)\end{array}$ \\
\hline Плеврит & IIIa & $15(60 \%)^{*}$ & $3(12 \%)$ \\
\hline Інші хірургічні ускладнення & IIIb & $5(20 \%)$ & $1(4 \%)$ \\
\hline Анемія легкої та середньої & I & $7(28 \%)^{\star}$ & $15(60 \%)$ \\
\hline тяжкості & & & \\
\hline Токсичне ураження печінки & II & $4(16 \%)$ & $2(8 \%)$ \\
\hline Гостре ураження нирок & II & $2(8 \%)$ & $2(8 \%)$ \\
\hline Тяжка анемія & II & $14(56 \%)^{\star}$ & $4(16 \%)$ \\
\hline $\begin{array}{l}\text { Гастростаз або динаміч- } \\
\text { на КН }\end{array}$ & II & $2(8 \%)$ & $1(4 \%)$ \\
\hline Панкреатит & II & $3(12 \%)$ & $1(4 \%)$ \\
\hline
\end{tabular}

${ }^{*} \mathrm{p}<0,05$ - різниця між досліджуваною і контрольною групою статистично значуща

Таблиця 5. Безпосередні (короткострокові) результати лікування хворих досліджуваної та контрольної груп

\begin{tabular}{|c|c|c|}
\hline Показник & $\mathrm{PCl} \geqslant 12(\mathrm{n}=25)$ & $\mathrm{PCl}<12(\mathrm{n}=25)$ \\
\hline $\begin{array}{l}\text { Тривалість перебування в реаніма- } \\
\text { ційному відділенні (кількість днів } \\
\text { після операції) }\end{array}$ & $2,64 \pm 0,4^{*}$ & $1,52 \pm 0,32$ \\
\hline $\begin{array}{l}\text { Тривалість перебування в стаціо- } \\
\text { нарі (кількість днів після операції) }\end{array}$ & $13,24 \pm 1,01^{*}$ & $9,44 \pm 0,75$ \\
\hline $\begin{array}{l}\text { Термін початку АПХТ (кількість днів } \\
\text { після операції) }\end{array}$ & $24,04 \pm 3,03$ & $19,52 \pm 2,2$ \\
\hline
\end{tabular}

${ }^{*} \mathrm{p}<0,05$ - різниця між досліджуваною і контрольною групою статистично значуща

травмою під час ЦРО у таких хворих, а також більш частим виникненням ускладнень хірургічного та нехірургічного профілю у них.

\section{висновки}

1. ЦРО у хворих з високим РСІ ( $\geqslant 12)$ - це високоагресивне лікування, яке негативно впливає на функціонування життєво важливих органів і систем пацієнток.

2. Плеврит та анемія тяжкого ступеня є найчастішими ускладненнями післяопераційного періоду, що достовірно частіше $(\mathrm{p}<0,05)$ виявляють у хворих з високим РСІ після ЦРО.

3. ЦРО у хворих з високим РСІ подовжують терміни післяопераційного лікування як у відділенні реанімації, так і в стаціонарі в цілому.

4. Високий PCI $(\geqslant 12)$ у поєднанні з сумнівною перспективою виконання повної циторедукції (можливість досягнення рівня R0 щодо резидуальної пухлини), наявність важкої супутньої патології є критеріями вибору неоад'ювантної поліхіміотерапії у стратегії лікування РЯ IIIc-IV стадій

\section{СПИСОК ВИКОРИСТАНОÏ ЛІТЕРАТУРИ}

1. Рак в Україні, 2019-202. Захворюваність, смертність, показники діяльності онкологічної служби: Бюлетень Національного канцер-реєстру №22/ Нац. ін.-т раку. - Кропивницький: ПОЛІУМ, 2021. - 135 с.

2. Querleu D., Planchamp F., Chiva L., Fotopoulou C., Barton D., Cibula D., ... duBois A. (2017). European Society of Gynaecological Oncology (ESGO) Guidelines for Ovarian Cancer Surgery. International Journal of Gynecological Cancer, 27(7), 1534-1542. doi: 10.1097/IGC.0000000000001041.

3. Ayhan A., Reed N., Gultekin M., Dursum P. Textbook of gynaecological oncology. Gunes Publishing, 2018. $1655 \mathrm{p}$.

4. Colombo N., Sessa C., du Bois A., Ledermann J., McCluggageW. G., McNeish I.,... Querleu D. (2019). ESMO-ESGO consensus conference recommendations on ovarian cancer: pathology and molecular biology, early and advanced stages, borderline tumours and recurrent disease. Annals of Oncology, 30:672-705. doi: $10.1093 /$ annonc/mdz062 
The role of the peritoneal carcinomatosis index in the treatment strategy for stage IIIc-IV serous ovarian cancer

V.S. Svintsitsky, M.Yu. Yegorov

National Cancer Institute, Kyiv

Ovarian cancer (OC) is one of the most aggressive and complex diseases of the female genital area. More than 3500 new cases of the disease are registered annually in Ukraine, $22.7 \%$ of patients die within the first year after diagnosis. This indicates the relevance of the development of new and optimization of existing programs for the treatment of ovarian cancer. Aim. To analyze the results of treatment of patients with primary advanced serous ovarian cancer with a high index of peritoneal carcinomatosis $(\mathrm{PCI} \geqslant 12)$ according to the following indicators: the degree of aggressiveness of the surgical intervention, postoperative complications, the length of stay in the intensive care unit and hospital, the timing of chemotherapy initiation, in comparison with the group of patients with low PCI $(<12)$ after cytoreductive surgery. Materials and methods. The results of treatment of 50 patients with advanced serous ovarian cancer who were treated at the Department of Oncogynecology of the National Cancer Institute from 2016 to 2020 were analyzed. The Surgical Complexity Scoring System was used to estimate the volume of surgical procedures, which provides a quantitative assessment of each surgical procedure. 50 patients were divided into two groups equally depending on the value of the PCI: $\geqslant 12-25$ patients - the study group and PCI $<12-25$ patients - the control group. Results. At the end of the 1 st day of the postoperative period (POD-0), statistically significant changes $(p<0.05)$ were found in alanine aminotransferase and aspartate transaminase levels in patients with $\mathrm{PCI} \geqslant 12$, which indicates the development of liver dysfunction in this group. Pleurisy and severe anemia are the most frequent complications of the postoperative period, much more often $(\mathrm{p}<0.05)$ are found in patients with a high index of peritoneal carcinomatosis compared with the control group. A statistically significant difference $(\mathrm{p}<0.05)$ was found in the length of stay of patients in the intensive care unit and hospital between the study and control groups. Thus, patients with PCI $\geqslant 12$ stayed in the intensive care unit and hospital after cytoreductive surgerysignificantly longer. Conclusions. The data obtained indicate that cytoreductive surgery in patients with a high index of peritoneal carcinomatosis is an extremely aggressive procedure, significantly disrupts the functioning of a number of organs and body systems, increases the number of surgical and non-surgical complications in the postoperative period, and lengthens the inpatient treatment of such patients. A high PCI $(\geqslant 12)$ in combination with a dubious prospect of performing complete cytoreduction (the possibility of reaching the $\mathrm{R} 0$ level for a residual tumor), the presence of severe concomitant pathology are the criteria for choosing neoadjuvant polychemotherapy in the strategy of treatment of stage IIIc-IV ovarian cancer.

Key words: serous ovarian cancer; surgery; cytoreduction; index of peritoneal carcinomatosis.

\section{Роль индекса перитонеального карциноматоза в стратегии лечения серозного рака яичников IIIc-IV стадий$$
\text { В.С. Свинцицкий, М.Ю. Егоров }
$$

Национальный институт рака, Киев

Рак яичников (РЯ) - одно из наиболее агрессивных и сложных заболеваний женской половой сферы. В Украине ежегодно регистрируется более 3500 новых случаев заболевания, $22,7 \%$ больных умирают в течение первого года после установления диагноза. Это указывает на актуальность разработки новых и оптимизации существующих программ лечения РЯ. Цель. Проанализировать результаты лечения больных с первичным распространенным серозным РЯ с высоким индексом перитонеального карциноматоза (peritoneal cancer index - PCI $\geqslant 12$ ) по следующим показателям: степень агрессивности хирургического вмешательства, послеоперационные осложнения, длительность пребывания в отделении реанимации и стационаре, сроки начала химиотерапии, по сравнению с группой больных с низким PCI $(<12)$ после циторедуктивной операции. Материалы и методы. Были проанализированы результаты лечения 50 больных с распространенным серозным РЯ, проходивших лечение в отделении онкогинекологии Национального института рака с 2016 по 2020 г. Для оценки объемов хирургических процедур была использована система оценки сложности хирургического вмешательства, что обеспечивает количественную оценку каждой хирургической процедуры. 50 больных были разделены на две группы поровну в зависимости от значения PCI: $\geqslant 12-25$ больных - исследуемая группа и РСI < 12 - 25 больных - контрольная группа. Результаты. В конце 1-го дня послеоперационного периода (POD-0) были выявлены статистически значимые изменения $(\mathrm{p}<0,05)$ уровней аланинаминотрансферазы и аспартатаминотрансферазы у больных с PCI $\geqslant 12$, что свидетельствует о развитии нарушения функции печени в этой группе. Плеврит и анемия тяжелой степени являются самыми частыми осложнениями послеоперационного периода, значительно чаще $(\mathrm{p}<0,05)$ отмечаются у больных с высоким PCI по сравнению с контрольной группой. Выявлена статистически достоверная разница $(\mathrm{p}<0,05)$ в продолжительности пребывания больных в отделении реанимации и стационаре между исследуемой и контрольной группами. Так, больные с PCI $\geqslant 12$ находились в отделении реанимации и стационаре после циторедуктивной операции достоверно дольше. Выводы. Полученные данные указывают на то, что проведение циторедуктивной операции у больных с высоким PCI является чрезвычайно агрессивной процедурой, существенно нарушает функционирование ряда органов и систем организма, увеличивает количество осложнений хирургического и нехирургического профиля в послеоперационный период, удлиняет сроки стационарного лечения таких больных. Высокий РСI ( $\geqslant 12)$ в сочетании с сомнительной перспективой выполнения полной циторедукции (возможность достижения уровня R0 по резидуальной опухоли), наличие тяжелой сопутствующей патологии являются критериями выбора неоадъювантной полихимиотерапии в стратегии лечения рака яичников IIIc-IV стадий.

Ключевые слова: серозный рак яичников; хирургическое лечение; циторедукция; индекс перитонеального карциноматоза.

Адреса:

Єгоров Михайло Юрійович

03022, Київ, вул. Ломоносова 33/43

Національний інститут раку

E-mail:yegorovmichael@gmail.com 